\title{
既約分解法による耐故障型飛行制御系の設計*1 \\ Design of a Failure Tolerant Flight Control System via Coprime Factorization Method
}

\author{
亀 山 丈 晴*2 ・越 智 徳 昌*2 \\ Takeharu Kameyama and Yoshimasa OCHI
}

Key Words : Failure Tolerant Flight Control, Normalized Coprime Factorization, $\nu$-Gap Metric, Coprime Factorization, Closed-Loop Identification

\begin{abstract}
This paper presents a design method of reconfigurable flight control systems based on the coprime factorization method. The baseline robust control system is designed using the normalized coprime factorization method. The identification method employed is a closed-loop one, which is also based on coprime factorization; therefore, the method is suitable to the robust control system. The $\nu$-gap metric is chosen as a criterion that indicates the effects of failures on stabilizability of the robust control system. The $\nu$-gap metric can be computed using the identified parameters. To illustrate the effectiveness of the control and identification method, a design example and simulation results for the F-18 HARV are shown.
\end{abstract}

記 号 の 説 明

$$
\left[\begin{array}{l|l}
A & B \\
\hline C & D
\end{array}\right]=C(s I-A)^{-1} B+D
$$

1. は じめに

制御系は制御対象の動特性の変動やモデル化誤差, 動作 環境の変化に対してロバストでなければならない．しかし， 制御性能に重大な影響を与える故障に対してはロバス卜性 だけでは不十分であり, 故障の影響を検知し，光れを抑え る対策 (自己修復機能) が必要になる.特に故障が発生し た後も動作を続けなければならない飛行制御系においては この問題は重要となる. そこてて航空機が飛行中に故障した 場合に，自動的に制御系を修正して故障から回復する制御 系として再構成可能な飛行制御系というアイデアが提案さ れ，多くの研究が報告されている1〜11).

筆者の一人はこれまでに「自己修復飛行制御システムの研 究 $\lrcorner^{12 \sim 14)}$ として, 正規化既約分解法 (Normalized Coprime Factorization (NCF) Method) ${ }^{15)}$ を用いたロバスト制御則 及び故障情報を既知とした再構成則を設計し，数学シミュ レーション及び動的風洞試験にて評価を行った . 本研究で は, これらの研究結果を基に, 残された課題である故障の 検出同定を行う方法について考える．

故障検出同定法には大きく分けて 2 通りの方法がある 一つは多重仮説検定法 ${ }^{16)}$ である .これは，まず故障に関す

*1 (C) 2005 日本航空宇宙学会

平成 15 年 10 月 8 日, 第 41 回飛行機シンポジウムにおいて発 表. 平成 16 年 10 月 15 日原稿受理

*2 防衛大学校
る多くの仮説を設け, 弚れらが正しい確率を求め, 关の中 で最も正しいと思われる仮説を採用して故障検出・分離 · 診断を実施するものである . 仮説検定には多くの方法が提 案されているが, 仮説に基づいたモデルを構築し , モデル ごとのカルマンフィルタあるいはオブザーバの出力信号と プラントの観測信号との残差を用いて検定する方法 ${ }^{17)}$ が知 られている．ただし，仮説以外の故障に対しては脆弱であ る .もう一つは , パラメータ同定による方法 ${ }^{18)}$ である .こ れは, システムの挙動を記述する状態方程式あるいは伝達 関数のパラメータを最小自乗法等の同定アルゴリズムを用 いて推定するものである．ただし，具体的な故障箇所や故 障の種類の特定はできない．しかし，耐故障型飛行制御系 においては, 個々の故障を特定するより故障がシステムの 動特性に与える影響, 即ち故障後のシステムの動特性を知 ることが重要である. 従って, 本論文ではパラメータ同定 法を用いる .

具体的には，耐故障型飛行制御系のための故障検出同定法 として閉ループ系でのパラメータ同定法である既約分解法 (Coprime Factorization(CF)Method) ${ }^{19,20)}$ を採用し, 故 障の大きさ (モデル誤差) の指標として $\nu$ ギャップ距離 ${ }^{21,22)}$ を用いる23 26)

これらは以下の特徵をもつ.まず, 故障後の機体動特性 の推定のために採用した CF 法はロバスト制御則の設計に 用いた NCF 法との整合性がよく，見かけ上開ループシス テムとしてプラントパラメータを推定することができる . 閉ループ同定法であることから不安定な制御対象に対して も適用可能である. また, 自己修復飛行制御系のような耐 故障型飛行制御系では故障後のシステムの動特性を知るだ けでなく，故障が制御性能にどの程度の影響を与えるのか 
を知ることも重要である . 推定プラントから計算される $\nu$ ギャップ距離はコントローラから見た故障の度合を与える 重要な指標となりうる.また $\nu$ ギャップ距離は故障の有無を 判定する故障検出においても有効な指標として利用できる

以下ではまず次章で, 動的風洞試験結果をもとにパラメー 夕推定機構を耐故障型制御にどう組み込むかを説明する.第 3 章では, ロバスト制御設計手法である NCF 法の概要を述 ベ, 弚こで得られるロバスト安定余有とコントローラから 見たモデル誤差の指標である $\nu$ ギャップ距離との関係から 第 2 章の説明を補強する. 第 4 章では, 閉ループ系でのパ ラメータ同定法である既約分解法の概要を述べ, NCF コン トローラでの適用法を述べる.第 5 章では，F-18HARVに 提案する手法を適用して制御系の設計及びシミュレーショ ンを行い，有効性を検証する .

\section{2. 耐故障型飛行制御系}

耐故障型飛行制御系の設計法として固定コントローラに よるロバスト制御に基づく方法と制御パラメータをオンラ インで逐次修正する適応制御に基づく方法に大きく分けら れるが, 本論文では, 自己修復飛行制御系の研究で得られ た知見から，前者の方法により耐故障型飛行制御系を構成 する .

まず自己修復飛行制御の動的風洞試験から，次の結果が 得られた ${ }^{14)}$.

(1) 想定したモデル誤差に対して設計したロバスト制御則 により，模擬損傷に対しても十分にロバスト安定である。 (2) 比較的大きな模擬損傷に対しても，ロバスト安定であ るが, 制御性能が劣化する。しかし, 再構成則 (制御則 の修正) を働かせると，制御性能がかなり回復する．

(3) ロバスト制御則でも不安定になるような模擬損傷に対 しては，再構成則を働かせても，不安定である．

これらの結果から，本研究では耐故障型制御を次のよう に実施するものとする．すなわち，故障がない状態あるい は小さな故障が発生した場合にはロバスト制御則の有する ロバスト安定性にまかせる.従って , パラメータ推定機構 から得られた推定パラメータを用いて，コントローラをリ アルタイムで逐次修正する適応機構は組み込まない．ただ し, 推定パラメータを用いて得られる推定プラントとコン トローラの設計に用いたノミナルプラントとの差（故障に よるモデル誤差) の大きさに応じて再構成則を働かせる .こ こで故障によるモデル誤差は $\nu$ ギャップ距離で評価し，光 の值と制御則がもつロバスト安定余有の比較から再構成を 行うか否かを決定する.この手法を图示すると第 1 図のよ

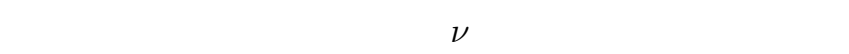
係については次章を参照されたい .

\section{3. 正規化既約分解法とモデル化誤差の尺度}

本研究における制御系設計及びパラメータ推定の基礎と なる NCF 法と安定化に対する故障の影響の尺度となるロ

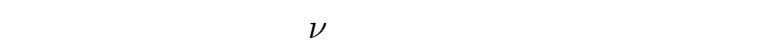

以下において $R H_{\infty}$ は安定プロパーな伝達関数の集合を表

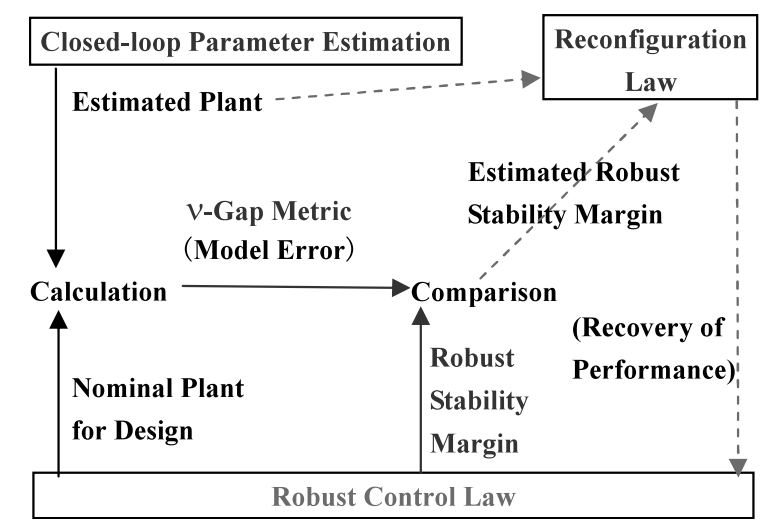

第1图 耐故障型飛行制御系の戦略

$P(s)$

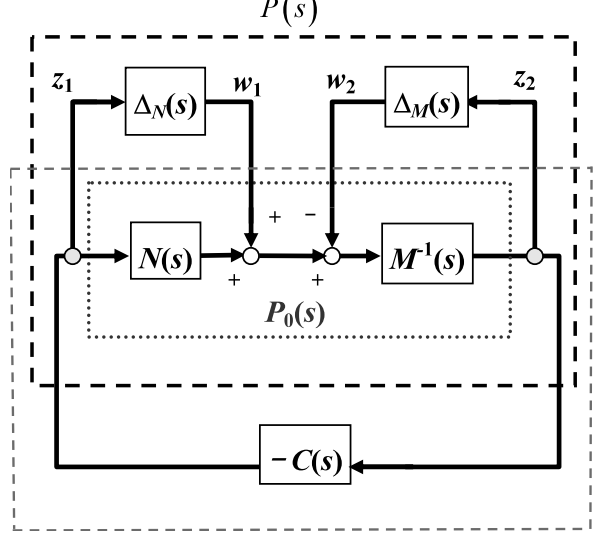

第 2 図＼cjkstart変動プラントに対する $\mathrm{NCF}$ 制御系

し，GH$H_{\infty}$ は逆行列も $R H_{\infty}$ に属す伝達関数の集合を表す．

3.1 正規化既約分解 (NCF) 法 $\mathrm{NCF}$ 法 $\left.{ }^{15}\right)$ は, プラ ント入出力信号からコントローラ入出力信号までの閉ルー プ伝達関数の $H_{\infty}$ ノルムをできるだけ小さくすることでで きるだけ大きなモデル誤差に対して安定性を保証するコン トローラを設計する手法である . NCF 法は, 開ループ系で のループ整形を行うことから古典制御に慣れ親しんだ現場 向きの手法である．混合感度法と比べて感度関数，相補感 度関数を制御対象の入出力端両方でバランス良く整形でき， 多入出力系にも有効な方法である.

ノミナルの制御対象 $P_{0}(s)$ をCF 表現

$$
P_{0}(s)=M(s)^{-1} N(s)
$$

で表現し，変動プラントを

$$
P(s)=\left(M(s)+\Delta_{M}\right)^{-1}\left(N(s)+\Delta_{N}\right)
$$

とする .ここで $\Delta_{N}, \Delta_{M}$ はある正の定数 $\varepsilon$ に対して次式 で定義される集合に属するとする．

$$
D_{\varepsilon}=\left\{\Delta=\left[\begin{array}{ll}
\Delta_{N} & \Delta_{M}
\end{array}\right] \mid \Delta \in R H_{\infty},\|\Delta\|_{\infty}<\varepsilon\right\}
$$

第 2 図の制御系において，すべての $\Delta \in D_{\varepsilon}$ に対し， $P(s)$ がコントローラ $C(s)$ で安定化されるようなモデル誤差 $\varepsilon$ 
の最大値 $\varepsilon_{\max }$ は

$$
\varepsilon_{\max }=\left(\inf _{c}\left\|T_{z w}(s)\right\|_{\infty}\right)^{-1}
$$

で与えられる ${ }^{15)}$. ここで，

$$
T_{z w}(s)=\left[\begin{array}{c}
C(s) \\
I
\end{array}\right]\left(I+P_{0}(s) C(s)\right)^{-1}\left[P_{0}(s) \quad I\right]
$$

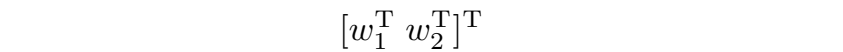
信号 $\left[\begin{array}{ll}z_{1}^{\mathrm{T}} & z_{2}^{\mathrm{T}}\end{array}\right]^{\mathrm{T}}$ までの閉ループ妘達関数である. NCF 法で は許容されるモデル誤差 $\varepsilon\left(\leq \varepsilon_{\max }\right)$ を先に指定してコント ローラを設計することができる .

3.2 モデル化誤差の尺度 ノミナルプラント $P_{0}(s)$ に 対して設計されたコントローラ $C(s)$ により許容されるモ デル誤差

$$
\varepsilon=\left(\left\|T_{z w}(s)\right\|_{\infty}\right)^{-1}
$$

はロバスト安定余有と呼ばれる ${ }^{15)}$. 小ゲイン定理より $\left\|\left[\begin{array}{ll}\Delta_{N} & \Delta_{M}\end{array}\right]\right\|_{\infty}<\varepsilon$ のモデル誤差を含むどんな変動プラ ントに対しても $C(s)$ により閉ループ系は安定となる .な お, $\varepsilon$ の最大值である $\varepsilon_{\max }$ はプラント $P_{0}(s)$ が与えられる とコントローラとは無関係に決まる值であり， $\varepsilon_{\max }$ がつぎ に述べる $\nu$ ギャップ距離 ${ }^{21,22)}$ より小さいと，想定されるプ ラントのモデル誤差に対して安定化するコントローラが存 在するとは限らない，従って， $\varepsilon_{\max }$ は許容される(すなわ ち補償可能な）最大のモデル誤差 (故障の程度) を表す指 標となる .

ノミナルプラント $P_{0}(s)$ と摂動プラント $P(s)$ の間に存 在するモデル誤差の指標として (3) 式より保守性の少ない 次式で定義される $\nu$ ギャップ距離

$$
\nu=\left\|\Psi\left(P(s), P_{0}(s)\right)\right\|_{\infty}
$$

を用いる.ここで

$$
\begin{aligned}
& \Psi\left(P, P_{0}\right) \equiv\left(I+P_{0} P_{0}^{\sim}\right)^{-\frac{1}{2}}\left(P-P_{0}\right)\left(I+P^{\sim} P\right)^{-\frac{1}{2}} \\
& P^{\sim}=P(s)^{\sim} \equiv P(-s)^{\mathrm{T}}
\end{aligned}
$$

である $\varepsilon>\nu$ である限り，コントローラ $C(s)$ は摂動プラ ントに対してもロバスト安定である ${ }^{21,22)}$. 従って,$\nu$ と $\varepsilon$ が分かれば $C(s)$ が安定化できる最大のモデル誤差に対し て摂動プラント $P(s)$ のモデル誤差がどの程度悪性のもの かが分かる.すなわち, $\nu$ ギャップ距離を，摂動プラントに 対して $C(s)$ が達成できる安定化の容易さの目安と見るこ

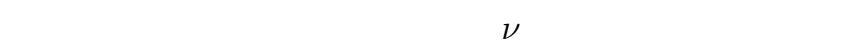

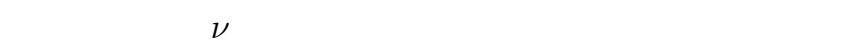
標となることが分かる .

なお，想定されるモデル誤差の $\nu$ ギャップ距離が $\varepsilon_{\max }$ を超える場合には, 第 3 図のように前置及び後置補償器 $V(s), W(s)$ を用いて開ループ伝達関数を整形した拡張プ

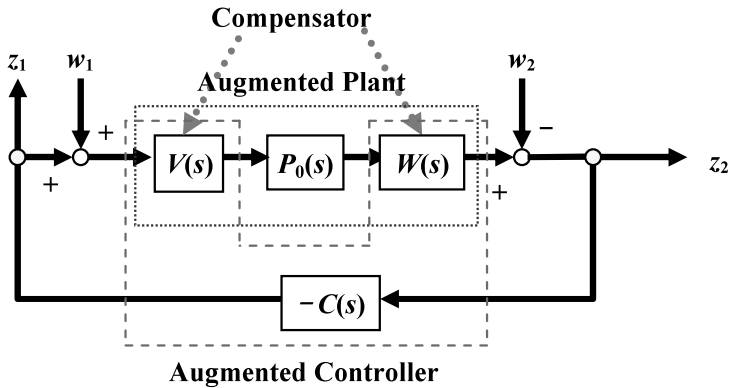

第 3 図 拡張プラントに対する $\mathrm{NCF}$ 制御系

ラント $W(s) P_{0}(s) V(s)$ を新たに制御対象とみなすことに より $\varepsilon_{\max }$ を大きくできロバスト安定化が達成できる可能

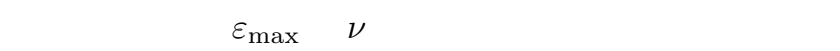
張プラントに対して安定化コントローラ $C(s)$ を設計する ことが可能となる. 乥して $V(s) C(s) W(s)$ を実際のコント ローラ (拡張コントローラ) とする .

\section{4. 既約分解法によるパラメータ同定}

一般に制御対象のパラメータを同定するには , 入力と出 力が独立でなければならない，ところが，閉ループ系では フィードバックコントローラを介して入力と出力が相関を もつので独立性が保証されず同定が困難になる ンラインで制御対象の動特性を知る必要がある耐故障型飛 行制御系では，この問題は重大になる.これに対処する一 つの方法が CF 法に基づくパラメータ同定法である ${ }^{19,20)}$.

ノミナルプラント $P_{0}(s)$ 及びコントローラ $C(s)$ の既約 分解表現を次のようにおく.

$$
\begin{aligned}
& P_{0}(s)=D_{0 l}(s)^{-1} N_{0 l}(s) \\
& C(s)=X_{r}(s) Y_{r}(s)^{-1}=Y_{l}(s)^{-1} X_{l}(s)
\end{aligned}
$$

閉ループ系が安定であれば次式のベズー等式を満たす安 定プロパーな伝详関数 $N_{0 l}(s), D_{0 l}(s), X_{r}(s), Y_{r}(s), X_{l}(s)$, $Y_{l}(s) \in R H_{\infty}$ 及び $U(s) \in G H_{\infty}$ が存在する.

$$
N_{0 l}(s) X_{r}(s)+D_{0 l}(s) Y_{r}(s)=U(s)
$$

このとき, 安定化補償器のパラメトリゼーションと同樣に任 意の安定プロパーな伝详関数 $R(s) \in R H_{\infty}$ を用いて $C(s)$ により安定化可能な変動プラントのモデル $P(s)$ が次式の ように表現できる .

$$
\begin{aligned}
P(s)= & \left(D_{0 l}(s)-R(s) X_{l}(s)\right)^{-1} \\
& \times\left(N_{0 l}(s)+R(s) Y_{l}(s)\right)
\end{aligned}
$$

(12) 式をブロック線図で表すと，第 4 図の点線で囲んだ 部分のようになる . (12) 式を $R(s)$ について解くと,

$$
\begin{aligned}
R(s)= & \left(D_{0 l}(s) P(s)-N_{0 l}(s)\right) \\
& \times\left(X_{l}(s) P(s)+Y_{l}(s)\right)^{-1} \\
= & D_{0 l}(s)\left(P(s)-P_{0}(s)\right) \\
& \times(C(s) P(s)+I)^{-1} Y_{l}(s)^{-1}
\end{aligned}
$$




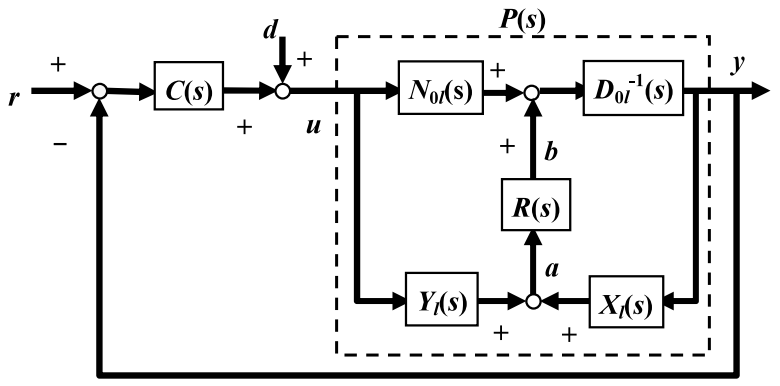

第 4 図 既約分解法によるプラント表現と閉ループ系

となる . (13) 式より, $R(s)$ の次数は一般に閉ループ系の次 数より大きく， $R(s)$ の極は閉ループ系の極を含んでいるこ とが分かる.

$R(s)$ への入出力を $a, b$ とすると, 第 4 図より

$$
\begin{aligned}
& a=X_{l}(s) r+Y_{l}(s) d \\
& b=D_{0 l}(s) y-N_{0 l}(s) u
\end{aligned}
$$

が成り立つ.ここで $r$ は参照信号,$d$ は外部入力信号であ る.$a$ は外部信号のみから生成されるので $b$ と独立と見な せる.従って,$b=R(s) a$ を, 開ループ系とみなして $R(s)$ のパラメータを推定することができる．ここでは連続時間 パラメータを離散時間的に同定するハイブリッド方式 ${ }^{28)}$ で 行い, 同定アルゴリズムは上下限トレースゲイン方式の最 小自乗法 ${ }^{29)}$ を用いる。

$R(s)$ のパラメータを推定値に置き換えたものを $\hat{R}(s)$ と する. $\hat{R}(s)$ か求まれば, (12) 式より未知の変動プラントの 伝達関数を次式のように推定できる.

$$
\begin{aligned}
\hat{P}(s)= & \left(D_{0 l}(s)-\hat{R}(s) X_{l}(s)\right)^{-1} \\
& \times\left(N_{0 l}(s)+\hat{R}(s) Y_{l}(s)\right)
\end{aligned}
$$

$\hat{R}(s)$ の次数は閉ループ系の次数以上であるから，(15) 式 より一般に $\hat{P}(s)$ は真のプラント $P(s)$ より高次となり, 真 のパラメータを推定することができない，しかし，次数が 異なっていても $\hat{P}(s)$ と $P(s)$ との $\nu$ ギャップ距離がほとん どなければ，安定化に影響する推定誤差はわずかであり口 バスト制御則にとって問題がないと言える.このように CF 法に基づくパラメータ同定法を用いるとパラメータ推定が できなくても，モデル推定及びモデル誤差の大きさ (すな

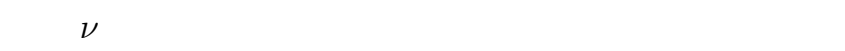
御系において重要な情報を得ることができる．なお，(15) 式により得られる推定プラントは通常低次元化ができ，実 プラントと同じ次数まで低次元化できれば真のパラメータ を得ることも可能となる. 弚の場合には, 必要に応じて, 得 られたパラメータの推定値を用いて制御則の修正が行える。

一般に (9)，(10)，(11) 式を満たす CF 表現は無数に存 在するが, 本論文では第 3 図のノミナルプラント $P_{0}(s)$ 及 び拡張コントローラ $C_{\mathrm{a}}(s)=V(s) C(s) W(s)$ に対して $\mathrm{CF}$ 法を適用する際に, $\mathrm{CF}$ 表現の一つであり一意的に算出で きる NCF 表現を用いることとする .

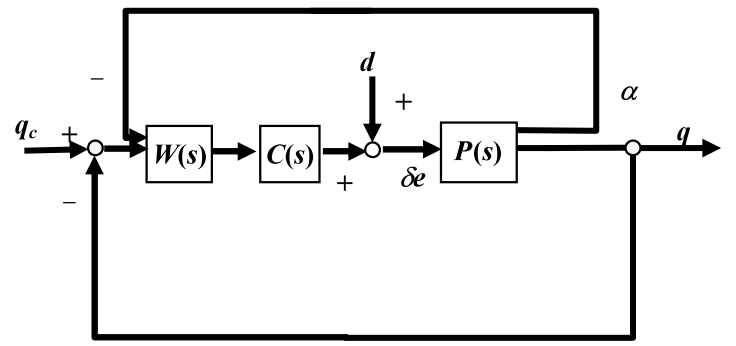

第 5 図＼cjkstart閉ループ系のブロック線図

5. シミュレーション

ノミナルの制御対象として高度 $9000 \mathrm{~m}$, 速度 $0.6 \mathrm{Mach}$ における F-18HARV の縦の運動方程式30)

$$
\left[\begin{array}{c}
\dot{\alpha} \\
\dot{q}
\end{array}\right]=A_{0}\left[\begin{array}{c}
\alpha \\
q
\end{array}\right]+B_{0} \delta_{\mathrm{e}}
$$

ここで

$$
A_{0}=\left[\begin{array}{cc}
-0.5088 & 0.994 \\
-1.131 & -0.2804
\end{array}\right], \quad B_{0}=\left[\begin{array}{c}
-0.09277 \\
-6.573
\end{array}\right]
$$

を考える.なお， $\alpha(\mathrm{rad})$ は迎角， $q(\mathrm{rad} / \mathrm{sec})$ はピッチレー 卜， $\delta_{\mathrm{e}}(\mathrm{rad})$ はエレベータ舵角である.伝達関数では次式 のように与えられる .

$$
P_{0}(s)=\frac{1}{s^{2}+0.7892 s+1.267}\left[\begin{array}{c}
-0.09277 s-6.56 \\
-6.573 s-3.239
\end{array}\right]
$$

閉ループ系をピッチレートコマンド方式で構成するため，1 次のループ整形補償器 $W(s)=\operatorname{diag}(0.1,1.4 / s)(\operatorname{diag}(\cdot)$ は・を対角要素とする対角行列) を用いて整形した拡張プラ ント $W(s) P_{0}(s)$ に対して , NCF 法によりコントローラを 設計する . 弚の結果, 次の 3 次のコントローラが得られる.

$C(s)=-\frac{1}{s^{3}+39 s^{2}+264 s+121}\left[\begin{array}{c}4.7 s^{2}+9.3 s+4.0 \\ 70 s^{2}+115 s+55\end{array}\right]^{\mathrm{T}}$

このとき, ロバスト安定余有は $\varepsilon=0.42$ である.実際のコン トローラ (拡張コントローラ) は 4 次のシステム $C(s) W(s)$ となる . また , 閉ループ系のブロック線図を第 5 図に示す . ここで, $q_{\mathrm{c}}(\mathrm{rad} / \mathrm{sec})$ はピッチレートコマンド,$P(s)$ は実 プラントである .

プラント $P_{0}(s)$ 及び拡張コントローラ $C(s) W(s)$ の $\mathrm{NCF}$ 表現は光れ艺れ 2 次の伝達関数 $N_{0 l}(s), D_{0 l}(s)$ 及び 4 次の 伝達関数 $X_{r}(s), Y_{r}(s), X_{l}(s), Y_{l}(s)$ を用いて以下のように 表される .

$$
N_{0 l}(s)=\frac{1}{\Delta_{1}}\left[\begin{array}{c}
-0.093 s-1.9 \\
-6.6 s-7.1
\end{array}\right]
$$




$$
D_{0 l}(s)=\frac{1}{\Delta_{1}}\left[\begin{array}{cc}
s^{2}+6.9 s+3.5 & -0.80 s-6.3 \\
-0.80 s+0.27 & s^{2}+1.4 s+2.2
\end{array}\right]
$$

ここで

$$
\begin{aligned}
& \Delta_{1}=s^{2}+7.5 s+7.4 \\
& X_{l}(s)=\frac{1}{\Delta_{2}}\left[\begin{array}{c}
-0.47 s^{3}-0.93 s^{2}-0.40 s \\
-98 s^{2}-161 s-77
\end{array}\right]^{\mathrm{T}} \\
& Y_{l}(s)=(23) \\
& X_{r}(s)=\frac{1}{\Delta_{2}}\left[\begin{array}{c}
-0.47 s^{3}-1.4 s^{2}-1.2 s-0.38 \\
-98 s^{2}-161 s-77
\end{array}\right]^{\mathrm{T}}
\end{aligned}
$$

$$
\begin{array}{r}
Y_{r}(s)=\frac{1}{\Delta_{2}}\left[\begin{array}{c}
s^{4}+40 s^{3}+302 s^{2}+268 s+77 \\
-0.0029 s^{3}+0.48 s^{2}+0.20 s \\
-0.0029 s^{3}-0.71 s^{2}-0.92 s-0.38 \\
s^{4}+40 s^{3}+264 s^{2}+121 s
\end{array}\right]
\end{array}
$$

ここで

$$
\Delta_{2}=s^{4}+40 s^{3}+302 s^{2}+268 s+77
$$

(20)，(21)，(22)，(25)，(26)，(27) 式を用いると (11) 式 を満たすので, $(20),(21),(22),(23),(24),(27)$ 式の 伝達関数を用いて $(14)$ 式より $a, b$ を生成して $R(s)$ を同定 し，さらに $(15)$ 式より $\hat{P}(s)$ を同定することができる .

故障等の影響で実際のプラントが以下のようにノミナル 值に対してシステム行列の縦の静安定係数及びピッチダン ピング係数が 0.1 倍, 舵効き行列が 0.5 倍に変動した場合 についてプラント及びレギャップ距離の推定を行う.

$$
\left[\begin{array}{c}
\dot{\alpha} \\
\dot{q}
\end{array}\right]=A\left[\begin{array}{c}
\alpha \\
q
\end{array}\right]+B \delta_{\mathrm{e}}
$$

ここで

$$
\begin{aligned}
A & =\left[\begin{array}{cc}
-0.5088 & 0.994 \\
-1.131 \times 0.1 & -0.2804 \times 0.1
\end{array}\right] \\
& =\left[\begin{array}{cc}
-0.5088 & 0.994 \\
-0.1131 & -0.02804
\end{array}\right] \\
& \equiv\left[\begin{array}{ll}
a_{11} & a_{12} \\
a_{21} & a_{22}
\end{array}\right] \\
B & =B_{0} \times 0.5=\left[\begin{array}{c}
-0.04639 \\
-3.287
\end{array}\right] \equiv\left[\begin{array}{l}
b_{11} \\
b_{21}
\end{array}\right]
\end{aligned}
$$

なお，伝達関数では次式のように与えられる .

$$
P(s)=\frac{1}{s^{2}+0.5368 s+0.1267}\left[\begin{array}{c}
-0.04638 s-3.268 \\
-3.287 s-1.667
\end{array}\right]
$$

変動プラントは未知であるが次数はノミナルプラントと 同じ 2 次であるとすると $R(s)$ の次数は $(13)$ 式より 8 次と なる. 従って,$R(s)$ を 8 次系として推定するものとする.

同定すべき帯域のモードを持続的に励起するために参照 信号 $r(t)=q_{c}(t)$ を 0 , 外部入力信号 $d(t)$ を $\mathrm{M}$ 系列信号と し ,フィルタの帯域幅をノミナル閉ループ系のピーク周波数 より大きな $3 \mathrm{rad} / \mathrm{sec}$, サンプリング周期を $10 \mathrm{msec}$ とする . このとき閉ループ系の入出力 $u, y$ の応答に対し , (14) 式よ り求めた一般化入出力 $a, b$ の応答を用いて推定した $\hat{R}(s)$ (8 次系) のパラメータの時間履歴を第 6 図に示す.ここ で凡例の真值は変動プラント (30) 式を既知として (20)〜 (24)，(27) 式とともに (13) 式に代入して得られる $R(s)$ の パラメータを用いた . 約 $16 \mathrm{sec} て ゙$ 推定值は収束しているが 真値には一致していない .

次に $\hat{R}(s)$ を (15) 式に代入して得られる推定プラント $\hat{P}(s)$ (14 次系) を 2 次系 $\hat{P}_{2 \mathrm{ord}}(s)$ に低次元化する . この とき出力二状態量であることを利用すると正則行列 $T$ によ

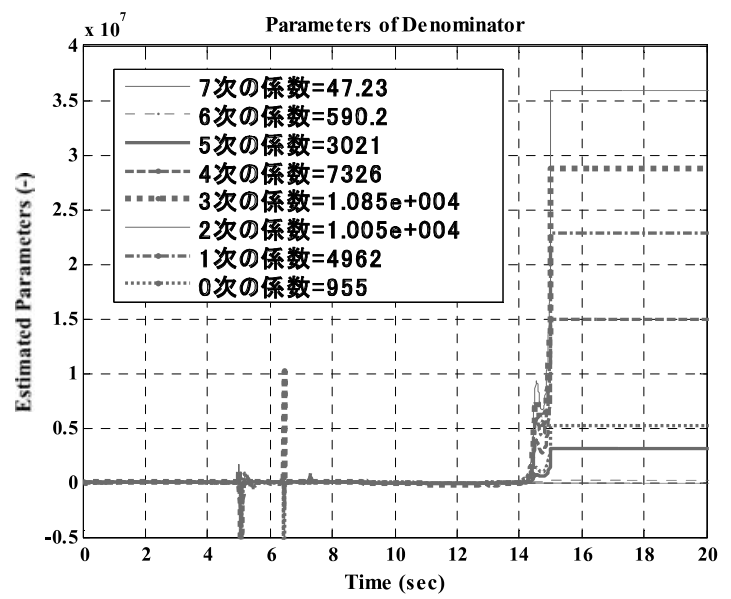

(a) $\hat{R}(s)$ の $(2,1)$ 成分のパラメータ (分母)

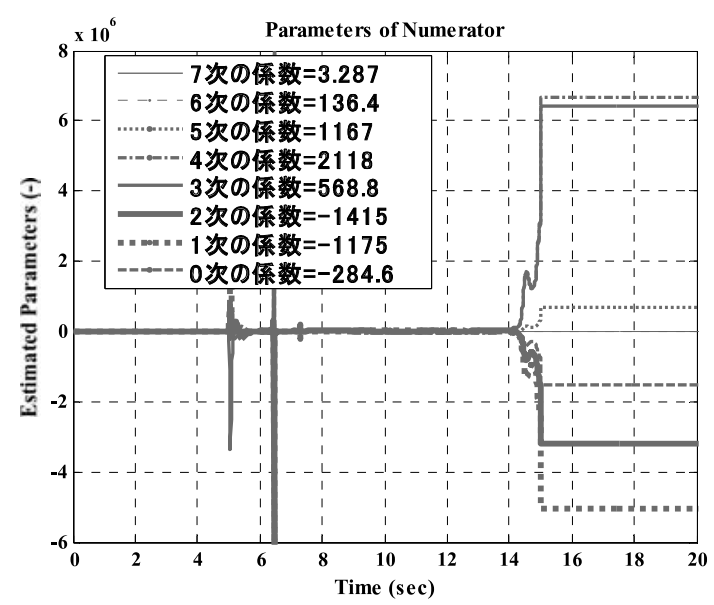

(b) $\hat{R}(s)$ の $(2,1)$ 成分のパラメータ (分子) 第6 図 $\hat{R}(s)$ のパラメータ 


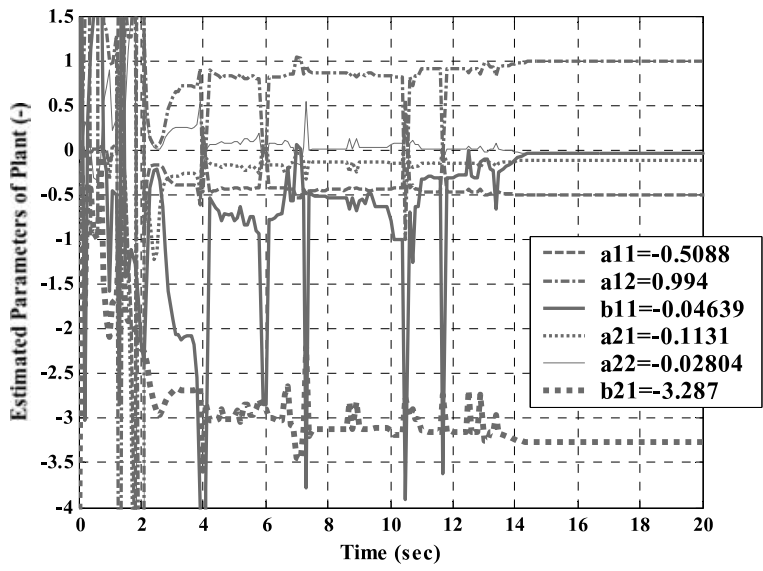

第 7 図 推定プラントを低次元化した際の状態空間表現における推定 パラメータ

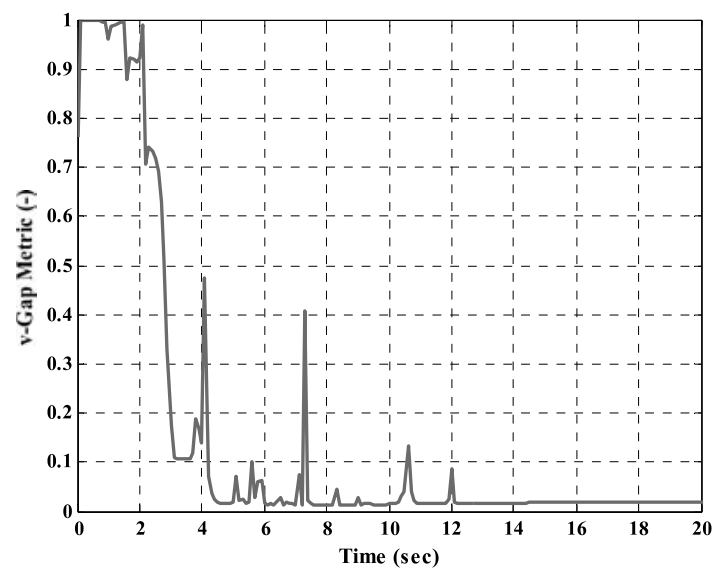

第 8 図 推定プラントと真のプラントとの $\nu$ ギャップ距離

り次のように相似変換できる .

$$
\begin{aligned}
\hat{P}_{2 \text { ord }}(s) & =\left[\begin{array}{c|c}
A_{2 \text { ord }} & B_{2 \text { ord }} \\
\hline C_{2 \text { ord }} & 0
\end{array}\right] \\
& =\left[\begin{array}{c|c}
T A_{2 \text { ord }} T^{-1} & T B_{2 \text { ord }} \\
\hline C_{2 \text { ord }} T^{-1} & 0
\end{array}\right] \\
& =\left[\begin{array}{c|c}
C_{2 \text { ord }} A_{2 \text { ord }} C_{\text {ord }}^{-1} & C_{2 \text { ord }} B_{2 \text { ord }} \\
\hline I & 0
\end{array}\right]
\end{aligned}
$$

(31) 式からプラントの状態空間表現における推定パラメー 夕 $\hat{A}=C_{2 \text { ord }} A_{2 \text { ord }} C_{2 \text { ord }}^{-1}, \hat{B}=C_{2 \text { ord }} B_{2 \text { ord }}$ を得ることがで きる. $\hat{A}, \hat{B}$ の時間履歴を第 7 図に示す . 推定值は約 $15 \mathrm{sec}$ で真值に収束している．これらの結果より， $R(s)$ のパラ メータ推定はできていないが, $P(s)$ のモデル推定はうま くいっていることがわかる .このことは, 第 8 図に示す推 定プラント $\hat{P}(s)$ と真のプラント $P(s)$ との $\nu$ ギャップ距離 $\nu$ が約 $15 \mathrm{sec}$ で $\nu=0.018$ に収束し， $\nu$ が十分小さいこと からも， $P(s)$ のモデル推定はうまくいっていることか確認 できる．しかし， $P(s)$ は未知なので本耐故障型飛行制御系 において実際に得られるのは第 9 図に示す拡張推定プラン 卜 $W(s) \hat{P}(s)$ と拡張ノミナルプラント $W(s) P_{0}(s)$ との $\nu$

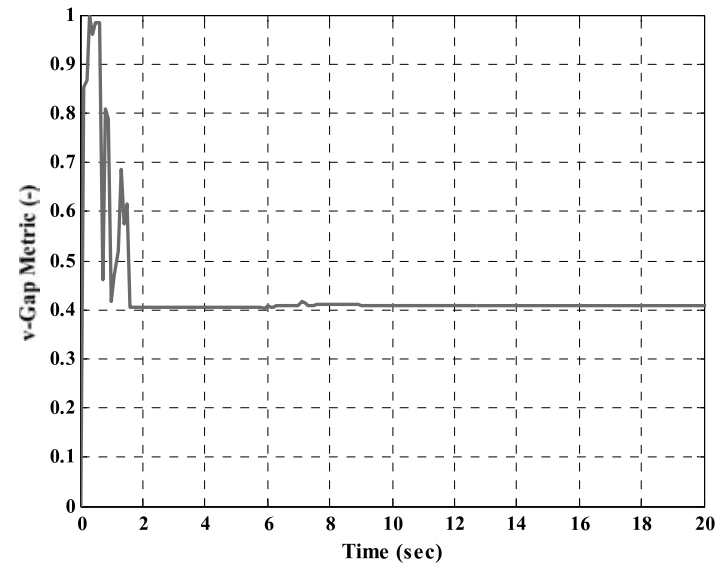

第 9 図 拡張推定プラントと拡張ノミナルプラントとの

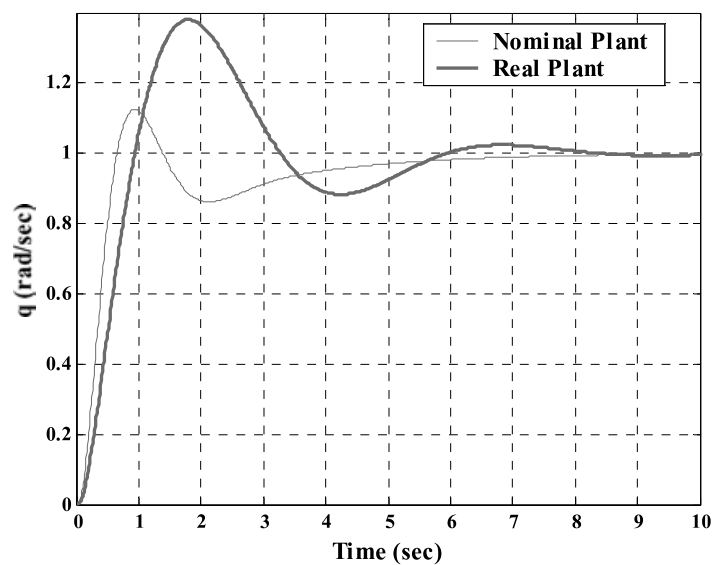

第10図 ノミナルプラントと変動プラントのステップ応答

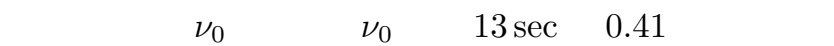
值 (0.41) にほぼ一致しており故障プラントのモデル推定が できている.さらに $\nu_{0}<\varepsilon(=0.42)$ であるが $\nu_{0} \approx \varepsilon$ であ ることから，推定モデルに対して閉ループ系はまだロバス 卜安定であるが実際の安定余有が大きく減少し制御性能が かなり劣化していることが推定される .このことはノミナ ルプラントと変動プラントのピッチレートコマンドに対す る閉ループ系のステップ応答を示す第 10 图からも確認で きる.このため，第 2 章で述べたように制御性能を回復す るために再構成則を起動する .ここでは CF 法から得られ る推定プラント $\hat{P}_{2 \text { ord }}(s)$ に基づいて NCF 法によりコント ローラを再設計するものとする . 再設計コントローラは次 式のように得られる .

$C_{\text {new }}(s)=-\frac{1}{s^{3}+31 s^{2}+160 s+73}\left[\begin{array}{c}4.1 s^{2}+6.8 s+2.4 \\ 64 s^{2}+87 s+30\end{array}\right]^{\mathrm{T}}$

変動プラントに対する再設計コントローラのロバスト安定 余有は $\varepsilon=0.37$ であり安定余有も改善されている.ここで 元のコントローラと再設計コントローラを用いた場合の変 動プラントのピッチレートコマンドに対する閉ループ系の ステップ応答を第 11 図に示す.制御性能が回復しているこ 


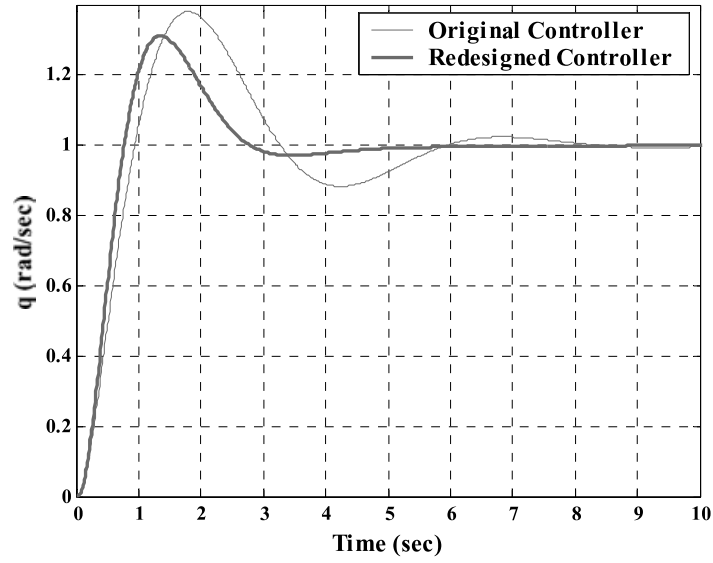

第 11 図 元のコントローラと再設計コントローラを用いた場合の変 動プラントのステップ応答

\section{とが分かる .}

\section{6. おわりに}

本論文では正規化既約分解 (NCF) 法によるロバスト制御 則で閉ループ系の安定性を維持しつつ，既約分解 $(\mathrm{CF})$ 同 定法により多入出力系の制御対象の閉ループ同定を行う耐 故障型飛行制御系を提案した . 故障の大きさは推定プラン トから計算されるレギャップ距離て評価した .この方法では

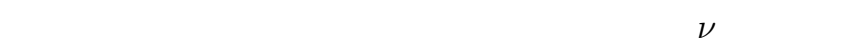
距離は十分小さく，モデル推定は可能であることをシミュ レーションで示した . また , 低次元化により真のプラント のパラメータを推定することも可能である .さらに プ距離は制御則修正の必要性を判断する指標として利用で きることを示した 。

本論文では，概念検証のため制御対象を線形系としノイ ズ無しの理想状態でシミュレーションを実施したが , 今後は 非線形系としてモデル化された制御対象に対して観測信号 にノイズを与えて有効性を検証していく必要がある . 観測 信号にノイズを与えた場合については, パラメータ推定と 状態推定を同時に実施することでプラント入出力信号 $u, y$ の推定入出力值及びパラメータ推定值が得られると考えら れる.

\section{参 考 文 献}

1) Eterno, J. S., Weiss, J. L., Looze, D. P. and Willsky, A.: Design Issues for Fault Tolerant Restructurable Aircraft Control, NASA TP-225, 1985.

2) Huber, R. R. and McCulloch, B.: Self-Repairing Flight Control System, SAE Technical Paper Series, 841552, 1984, pp. $1-20$.

3) Moerder, D. D., Halyo, N., Broussard, J. R. and Caglayan, A. K.: Application of Precomputed Control Laws in a Reconfigurable Aircraft Flight Control System, AIAA J. Guid. Control Dynam., 12 (1989), pp. 325-333.

4) Huang, C. Y. and Stengel, R. F.: Restructurable Control Using Proportional-Integral Implicit Model Following, AIAA J. Guid. Control Dynam., 13 (1990), pp. 303-309.

5) Napolitano, M. R., Naylor, S., Neppach, C. and Casdorph, V.: On-Line Learning Nonlinear Direct Neurocontrollers for Restructurable Control Systems, AIAA J. Guid. Control Dynam., 18 (1995), pp. 170-176.
6) Brinker, J. S. and Wise, K. A.: Reconfigurable Flight Control for a Tailless Advanced Fighter Aircraft, Proc. of AIAA Guidance, Navigation, and Control Conference, Boston, 1998, pp. $75-87$.

7) Werbos, P. J.: Neural Networks and Flight Control: Overview of Capabilities and Emerging Applications, Proc. of AIAA Guidance, Navigation, and Control Conference, Baltimore, 1995, pp. 912-919.

8) Rauch, H. E.: Autonomous Control Reconfiguration, IEEE Control Systems, 1995, pp. 37-48.

9) Morse, W. D. and Ossman, K. A.: Model Following Reconfigurable Flight Control System for the AFTI/F-16, AIAA J. Guid. Control Dynam., 13 (1990), pp. 969-976.

10) Enns, D.: Control Allocation Approaches, Proc. of AIAA Guidance, Navigation, and Control Conference, Boston, 1998, pp. 98-108.

11) Durham, W. C.: Efficient, Near-Optimal Control Allocation, AIAA J. Guid. Control Dynam., 22 (1999), pp. 369-371.

12）亀山丈晴, 瀬沼丈夫, 松本勇治, 井出正城, 清水英二, 久野哲郎, 安井久子, 後藤敬太 : 自己修復飛行制御システムの研究一制御方 式概要,第 36 回飛行機シンポジウム講演集, 1998, pp. 457-460.

13）増子洋一郎, 後藤敬太, 畠中洋史, 久野哲郎, 德田 映, 安井久 子, 亀山丈晴, 松本勇治, 大澤啓幸, 堀江和宏, 片岡健一郎 : 自 己修復飛行制御システムの研究一自己修復飛行制御系の設計，第 39 回飛行機シンポジウム講演集, 2001, pp. 315-321.

14）松本勇治, 亀山丈晴, 大澤啓幸, 片岡健一郎, 堀江和宏 : 自己修 復飛行制御システムの研究一動的風洞試験による評価結果，第 39 回飛行機シンポジウム講演集，2001, pp. 328-337.

15) McFarlane, D. C. and Glover, K.: Robust Controller Design Using Normalized Coprime Factor Plant Descriptions, Lecture Notes in Control and Information Sciences, No. 138, Springer-Verlag, New York, 1990.

16) Willsky, A. S.: A Survey of Design Methods for Failure Detection Systems, Automatica, 12 (1976), pp. 601-611.

17) Hajiyev, C. and Caliskan, F.: Fault Diagnosis and Reconfiguration in Flight Control Systems, Kluwer Academic Publishers, New York, 2003.

18) Ochi, Y. and Kanai, K.: Design of Restructurable Flight Control Systems Using Feedback Linearization, J. Guid. Control Dynam., 14 (1991), pp. 903-911.

19) Hansen, F. and Franklin, G.: On a Fractional Representation Approach to Closed-Loop Experiment Design, Proc. of ACC, Atlanta, 1988, pp. 1319-1320.

20) Hansen, F., Franklin, G. and Kosut, R.: Closed-Loop Identification via the Fractional Representation: Experiment Design, Proc. of ACC, Pittsburgh, 1989, pp. 1422-1427.

21) Vinnicombe, G.: Uncertainty and Feedback- $H_{\infty}$ LoopShaping and the $\nu$-Gap Metric, Imperial College Press, London, 2001.

22) Zhou, K. and Doyle, J. C.: Essentials of Robust Control, Prentice Hall, New Jersey (Upper Saddle River), 1998.

23）亀山丈晴, 越智德昌 : 正規化既約分解法によるロバスト制御と閉 ループ同定，第 41 回飛行機シンポジウム，2003, pp. 88-96.

24）亀山丈晴, 越智德昌 : 既約分解法によるロバスト制御と閉ループ 同定，第 20 回誘導制御シンポジウム，2003, pp. 99-106.

25) Kameyama, T.: Design of a Failure Tolerant Control System via Coprime Factorization Method, SICE Annual Conference 2004, 2004.

26) Kameyama, T.: Robust Control and Closed-Loop Identification by Normalized Coprime Factorization, ICAS 2004, 2004.

27) 足立修一: ユーザーのためのシステム同定理論, 計測自動制御学 会, 東京, 1993 .

28) Elliott, H.: Hybrid Adaptive Control of Continuous Time Systems, IEEE Trans. Automatic Control, AC-27 (1982), pp. $419-426$

29）新中新二 : 適応アルゴリズム一離散と連続, 真髄へのアプローチ, 産業図書, 東京, 1990 .

30) Adams, R. J., Buffington, J. M., Sparks, A. G. and Banda, S. S.: Robust Multivariable Flight Control, Springer-Verlag, New York, 1994. 